\section{Trial of an Experimental Castor Oil Solution for Cleaning Dentures}

Ingrid Machado de Andrade ${ }^{1}$, Kelly Machado de Andrade², Marina Xavier Pisani ${ }^{1}$, Cláudia Helena Silva-Lovato ${ }^{1}$, Raphael Freitas de Souza ${ }^{1}$, Helena de Freitas Oliveira Paranhos ${ }^{1}$
'Department of Dental Materials and Prosthetics, School of Dentistry of Ribeirão Preto, USP - University of São Paulo, Ribeirão Preto, SP, Brazil ${ }^{2}$ Department of Restorative Dentistry, School of Dentistry of Ribeirão Preto, USP - University of São Paulo, Ribeirão Preto, SP, Brazil

Correspondence: Profa. Dra. Helena de Freitas Oliveira Paranhos, Avenida do Café, S/N, 14040-904 Ribeirão Preto, SP, Brasil. Tel: +55-16-36024031. e-mail: helenpar@forp.usp.br

Key Words: denture biofilm, castor oil, sodium hypochlorite, alkaline peroxide, randomized controlled trial.

\section{Introduction}

The adequate maintenance of complete denture hygiene is of utmost importance for the health of edentulous patients. Biofilm accumulated on the internal surface of complete dentures may function as an important reservoir for bacterial and fungal pathogens (1). Oral microorganisms are involved not only in the appearance of local infections like denture stomatitis, but also in the appearance of systemic diseases such as endocarditis, pneumonia and respiratory tract infections (2).

Complete denture cleaning methods may be classified as mechanical, chemical or a combination of both. Brushing is the most frequently used mechanical method $(2,3)$ and is considered simple, inexpensive and effective (4-6). Nevertheless, such method may be challenging for patients with little dexterity and can wear denture base resins (7).

Chemical methods are considered as a feasible alternative for the elderly who need auxiliary methods for cleaning their dentures adequately (8). The best-known chemicals for denture hygiene are hypochlorite-based solutions and effervescent tablets mainly composed by alkaline peroxides (2). Alkaline peroxides are constituted by oxidant, effervescent, surface tension reducers and chelating agents. They are available in powder or tablet forms and are dissociated into hydrogen peroxide solutions after contact with water (9). These products have shown to be effective in biofilm removal and in reducing the number of mutans group streptococci on complete dentures $(8,10,11)$. Alkaline hypochlorite solutions are bactericidal and fungicidal and act by dissolving the organic matrix of biofilm, thus reducing the Candidaspp. counts on complete dentures (12). Nevertheless, two factors that make the acceptability of hypochlorite difficult are its unpleasant odor and residual taste.

Although there are chemical agents available on the market, none of them have ideal properties. Currently a product that has been extensively studied in all areas of health is the oil derived from castor bean (Ricinus communis). Castor oil can be used in innumerable industrial applications, such as paints, disinfectants, polymers, biofuels and pharmaceutical manufactures. In the medical field it has been studied and used in the form of a polymer for filling bone defects (13). In dentistry, the bactericidal and fungicidal potential of such biomaterial has encouraged new research to be conducted for application in Endodontics (14). In relation to complete dentures, Pinelli et al. (15) showed that a mouthwash based on castor oil (Perioquil) reduced the clinical signs of denture stomatitis and, regarding adverse effects, Pisani et al. $(16,17)$ found acceptable values for surface roughness, hardness and color of artificial teeth and resilient liner materials when a $2 \%$ $R$. communis solution was used. However, there are still 
no studies about the efficacy of the castor bean solution when used on complete denture biofilm.

Although denture-cleaning methods have been widely studied through the years, a recent systematic review showed that studies with a high level of evidence on the subject are scarce (18). In other words, there are few randomized controlled trials about such subject, and even fewer trials that used adequate methods. The lack of such studies is a major issue, as long as they are needed to provide solid support regarding which denture cleansing method is more effective than the other. Therefore, it can be stated that evidence that one cleaning product is better than the other in terms of biofilm removal is still inconclusive.

The aim of this study was to evaluate the efficacy of a castor bean-based solution for biofilm removal from complete dentures, by means of a cross-over, randomized design.

\section{Material and Methods}

Sixty patients treated at our Department of Dental Materials and Prosthetics were selected for the trial after the Institutional Review Board (CAAE 0007.0.138.000-08) approved the research protocol. Inclusion criteria were: 45 years of age or older, complete edentulism, good general health, use of maxillary complete dentures fabricated with heat-polymerized acrylic resin and acrylic artificial teeth. The exclusion criteria were: dentures that had been used for less than 3 years, and broken, fractured or relined dentures. There was no restriction regarding gender and all participants provided informed consent to be enrolled.

Participants received verbal, written and demonstrative instructions to brush the internal surface of their dentures for 2 min with specific brush (Denture; Condor SA, São Bento do Sul, SC, Brazil) and denture paste (Corega Refreshing Mint; Glaxosmithkline Brasil Ltda, Rio de Janeiro, RJ, Brazil), three times a day after meals (breakfast, lunch and dinner) and to use the following chemical immersion methods once a day (after dinner): saline for $20 \mathrm{~min}$ (control), 1\% sodium hypochlorite $(\mathrm{NaOCl})$ for $20 \mathrm{~min}$, Polident alkaline peroxide for $3 \mathrm{~min}$ and 2.0\% castor bean solution ( $R$. communis) for $20 \mathrm{~min}$. The recommended period for short immersions was used $(2,9)$, except for the alkaline peroxide solution, which was used for the period indicated by the manufacturer. In addition, the participants were instructed to remove their dentures overnight and keep them immersed in water for at least $8 \mathrm{~h}$. The participants used each of the four chemical methods for a period of 7 days in a random sequence. Following each period of use, there was a 1-week washout period during which the patient performed his/her habitual cleaning procedures.

On the first day and after 7 days using the interventions, the internal surfaces of all dentures were stained by a disclosing solution ( $1 \%$ neutral red) and photographed with a digital camera. The camera was placed on a stand with the objective facing the internal surface of the denture at an angle of $45^{\circ}$, in order to capture images from undercuts. The distance was determined by focusing on the central region of the palate of the largest denture. After obtaining the photographs, dentures were cleaned by researchers with a brush (Denture; Condor SA) and liquid soap (JOB Química, Monte Alto, SP, Brazil) and returned to the patients in a clinical adequately cleaned condition. Biofilm coverage area $(\%)$ on the internal surface was quantified on the photos by using the Image Tool 3.0 software (The University of Texas Health Science Center, San Antonio, TX, USA) $(4-6,10)$.

Seeking the blinding of the involved parts, the products were delivered to participants without identification and in the quantity needed for 7 days, being dispensed in unidentified vials (solutions) and sacks (tablets) plastics. The $P 1$ researcher obtained a list of random numbers (Excel 2013; Microsoft Brasil, São Paulo, SP, Brazil), corresponding to the possible sequences of interventions. The $\mathrm{P} 2$ researcher received random numbers and sent to $\mathrm{P} 3$, who distributed the products to participants numbering as received and provided guidelines for hygiene. The P4 researcher was responsible for the collection and subsequent total elimination of the biofilm. The P2 researcher performed the biofilm staining and obtained photographs of prostheses. The P5 researcher conducted the quantification of biofilm (Image Tool 3.0), tabulated the variables and forwarded the data to the researcher $\mathrm{P} 1$, who performed the statistical analysis. Thus, all researchers, as well as the participants, were blind to the treatments applied. After each 7 days of use, the patients answered a question about perceived adverse effects (odor or aftertaste) in an open format.

The parameters used for sample calculation were extracted from the comparison between brushing and the associated method (brushing and effervescent tablet) found by Paranhos et al. (4) with: $S D=5.32 \%, \alpha=0.05$ and $\beta=0.20$. Thus, the number of participants initially recruited was 55 , as this number of patients would enable the study to be completed with the expected number of samples $(n=46)$, even after the loss of up to $20 \%$ of the randomized sample.

The values did not adhere to normal distribution, as verified by the Kolmogorov-Smirnov test. Different solutions were compared by the Friedman test followed by multiple comparisons by the Wilcoxon test, corrected by the Bonferroni method. All the tests complied with a level of significance of 0.05 , except for the multiple comparisons $(\alpha=0.005)$, and were performed by the SPSS 15.0 software (SPSS Inc., Chicago, IL, USA).

\section{Results}

Sixty patients were evaluated for possible enrollment, 
of whom five were excluded because they did not wear maxillary complete dentures. Of the 55 remaining patients, five did not return to the clinic after 7 days of using one of the treatments, and were excluded from the statistical analysis. Reasons for withdrawals were impossibility to leave his workplace $(n=1)$; inability to arrange transport $(n=1)$, and systemic health problems $(n=3)$. Thus, the final sample of this study consisted of 50 patients ( 14 men and 36 women) with mean age of 63 years (range: 50 to 85 years).

By means of the Friedman test, significant differences were observed among tested methods ( $F r=51.67 ; p<0.001)$. Table 1 contains the mean ranks obtained by the test, as well as the results of multiple comparisons. It shows that all treatments significantly differed from the baseline evaluations. Despite the significant lower biofilm coverage for $1 \% \mathrm{NaOCl}$ in comparison with the control solution, the castor oil solution and alkaline peroxide presented intermediate values (Fig. 1).

No adverse effect on the denture material or oral tissues was observed. According to the reports, only two participants complained about the odor of $\mathrm{NaOCl}$. Nevertheless, in spite of their comments, they did not feel discouraged about using the product correctly as they had been instructed. Only one participant complained about the odor of the castor oil solution. No patient complained about the alkaline peroxide-based effervescent tablets.

\section{Discussion}

In the present study, the efficacy of a castor oil solution was evaluated for the removal of complete denture biofilm, and was compared to two traditional products $(1 \% \mathrm{NaOCl}$ and alkaline peroxide). The results showed that all cleaning treatments significantly differed from the baseline (control). $\mathrm{NaOCl}$ showed the lowest percentage of biofilm followed by the castor bean-based solution and alkaline peroxide tablet, whereas the saline showed the highest post-treatment biofilm rates.

Previous studies have reported the efficacy of $\mathrm{NaOCl}$ employed as a complete denture cleaner $(12,19)$, and some

Table 1. Mean ranks and pairwise comparisons of the different methods

\begin{tabular}{ll}
\hline Methods & Mean Ranks \\
\hline Baseline & $4.18 \mathrm{a}$ \\
Polident & $2.92 \mathrm{~b}, \mathrm{c}$ \\
Saline & $3.18 \mathrm{~b}$ \\
$\mathrm{NaOCl}$ & $2.16 \mathrm{c}$ \\
Castor bean & $2.56 \mathrm{~b}, \mathrm{c}$ \\
\hline
\end{tabular}

*Different letters indicate statistically significant difference among the methods (Friedman's test; $p<0.05$ ). of them also evaluated clinically the efficacy of $\mathrm{NaOCl}$ and even Polident in biofilm removal from complete dentures $(8,11,20)$. These studies showed the efficacy of this solution when used as an isolated method, at concentrations of $0.5 \%$ (21), $1 \%$ and $5 \%$ (20). Such solutions were more effective than alkaline peroxides $(20,21)$ and can have their action increased by long periods of immersion (19). Our results showed, by means of a randomized clinical trial, that $1 \%$ $\mathrm{NaOCl}$ combined with the mechanical method of brushing can be effective in removing denture biofilm.

The castor oil solution ( $R$. communis) resulted in lower biofilm coverage compared to the baseline. The results for this experimental solution were intermediate to those obtained by a sham procedure and $1 \% \mathrm{NaOCl}$. Although such statistical results should be interpreted carefully, the castor oil solution seems to remove biofilm as a proprietary alkaline peroxide-based cleanser. The main component of castor oil is sodium ricinoleate (22), which may inhibit biofilm formation (23), but its mechanism of action is still unknown. Mordenti et al. (24) reported that the treatment with ricinoleate is correlated with a significant drop in acid production in biofilm. According to these studies, the detergent action of this product against microorganisms is associated to cell wall damages permitting the cytoplasmic components loss and consequently cell death.

Alkaline peroxide products consist of a combination of active ingredients, primarily designed to act on the organic constituents of biofilm and debris. When the tablet is dissolved in water, it releases alkaline hydrogen peroxides. Such peroxides decompose following contact with certain substances and release small oxygen bubbles, which can detach biofilm from denture materials (9). Previous clinical

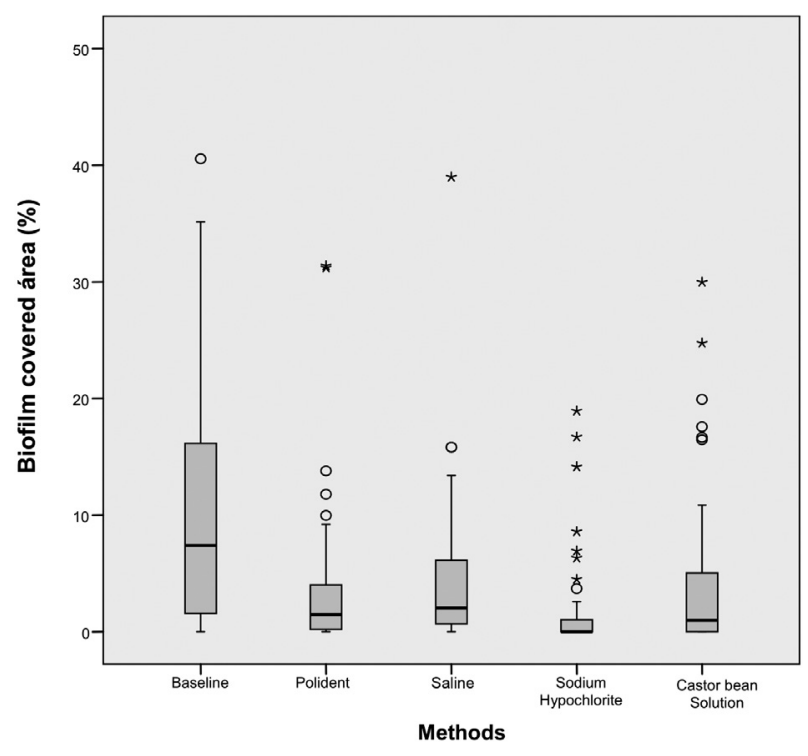

Figure 1. Area covered with biofilm after the use of each product. 
studies regarding complete denture also observed good results with alkaline peroxide as regards the property of biofilm removal (10) and antimicrobial action against specific microorganisms (11).

A fact that may explain the similarity of the results of both products (castor oil and alkaline peroxide) is the selectivity of action on different microbial species. $R$. communis, as a detergent product (22), acts on the cell wall matrix by glycosidic bond splitting, or wall rupture (24). This product has a more specific action against grampositive bacteria. The alkaline peroxide, as an oxidant product, may affect vital areas of the cell and generate in situ hydroxyl radicals, which exert a more specific action against anaerobes (25). In this way, despite having different mechanisms of action, i.e., one causing the lysis of cell wall and the other oxidizing the microbial cell, due to their selective action, both products showed similar effects against denture biofilm. On the other hand, $\mathrm{NaOCl}$, which has broad and unspecific action (19), and therefore greater efficacy, led to the lowest percentages of biofilm removal.

The reduction in biofilm levels following treatment was evident even after using saline. That may be explained, as seen in other studies $(4-6,10)$ by the implementation of $\therefore$ a standardized brushing routine, that is, brushing of the dentures three times a day with specific hygienic products, or even by patient motivation due to the enrollment in the trial. As expected for a sham treatment $(10,11)$, saline resulted in the highest percentages of biofilm.

This study sought to minimize the occurrence of bias, and, whenever possible, blind the parts involved (researchers and participants), since none of them had knowledge of the allocation of treatments. The participants were encouraged to attend return appointments, which may be verified by the small number of withdrawals until the end of the study. However, a limitation of the present research was the possible identification of $\mathrm{NaOCl}$ by participants due to its characteristic odor. Moreover, effervescent tablets could not be concealed at all. This limitation did not hinder the results of the study, as all the participants reported having used the solutions similarly and as instructed.

For further research, some important factors must be investigated, such as the antimicrobial action of tested denture cleansers and the possible adverse effects caused to prosthetic materials, in order to establish a complete denture cleansing protocol by the combination of brushing and use of castor bean solution as the immersion product. The solution's mechanism of action should be further elucidated in order to define its clinical applications. It should also be mentioned the exploratory nature of this study, as long as we considered a series of treatments and few outcome variables. Thus, future studies could investigate the efficacy of the castor oil solution versus a single comparator and a series of outcomes.

It can be concluded that the castor oil solution for short-term immersion was comparable to an alkaline peroxide solution in terms of efficacy on biofilm removal. Both solutions presented intermediate efficacy compared with a sham solution and $1 \% \mathrm{NaOCl}$.

\section{Resumo}

A higiene de próteses totais é essencial, uma vez que o biofilme da prótese está envolvido com infecções orais e doenças sistêmicas. Apesar de existirem agentes químicos disponíveis no mercado, nenhum deles apresenta propriedades ideais e pesquisas com esses produtos ainda são necessárias. 0 objetivo neste estudo foi avaliar a eficácia de uma solução de mamona (Ricinus communis) para a remoção do biofilme de prótese total, comparada com dois produtos comerciais ( $\mathrm{NaOCl}$ e peróxido alcalino). Cinqüenta usuários de próteses totais maxilares foram instruídos a escovar as próteses após as refeições e imergi-las uma vez por dia nas seguintes soluções: soro fisiológico (20 min), Peróxido alcalino Polident (3 min), $\mathrm{NaOCl}$ a $1 \%$ (20 min) e solução de mamona (20 min). Os participantes utilizaram cada solução por um período de sete dias consecutivos, de acordo com uma sequência aleatória. Após cada periodo, as superficies internas das próteses totais superiores foram coradas com solução evidenciadora (vermelho neutro a 1\%), fotografadas e o biofilme evidenciado foi quantificado com software. A influência dos tratamentos sobre os resultados foi verificada pelo teste de Friedman $(\alpha=0,05)$. Houve diferença significativa entre as soluções $(F r=51,67 ; p<0,001)$. 0 soro fisiológico e o $\mathrm{NaOCl}$ foram significativamente diferentes (mediana: 2,0\% e 0,0\%), enquanto o Polident e a solução de mamona apresentaram resultados intermediários (mediana: 1,0\% e 1,5\%, respectivamente). Concluiu-se que a solução de mamona avaliada é comparável ao peróxido alcalino, em termos de remoção do biofilme de prótese total.

\section{Acknowledgements}

The authors thank the São Paulo State Research Support Foundation FAPESP (Grant \#07/59850-2) for financial support and Professor Gilberto Orivaldo Chierice (Institute of Chemistry of São Carlos, University of São Paulo), for providing the castor oil solution.

\section{References}

1. Andre RFG, Andrade IM, Silva-Lovato CH, Paranhos HFO, Pimenta FC, Ito IY. Prevalence of mutans streptococci isolated from complete dentures and their susceptibility to mouthrinses. Braz Dent J 2011;22:62-67.

2. Felton D, Cooper L, Duqum I, Minsley G, Guckes A, Haug S, et al.. Evidence-based guidelines for the care and maintenance of complete dentures: a publication of the American College of Prosthodontics. J Prosthodont 2011;20:S1-S2.

3. Peracini A, Andrade IM, Paranhos HFO, Silva-Lovato $\mathrm{CH}$, Souza RF. Behaviors and hygiene habits of complete denture wearers. Braz Dent J 2010;21:247-252.

4. Paranhos HFO, Silva-Lovato $\mathrm{CH}$, Souza RF, Cruz PC, Freitas KM, Peracini A. Effects of mechanical and chemical methods on denture biofilm accumulation. J Oral Rehabil 2007;34:606-612.

5. Andrade IM, Silva-Lovato $\mathrm{CH}$, Souza RF, Pisani MX, Andrade KM, Paranhos HFO. Trial of experimental toothpastes regarding quality for cleaning dentures. Int J Prosthod 2012;25:157-159.

6. Paranhos HFO, Salles AES, Macedo LD, Silva-Lovato $\mathrm{CH}$, Pagnano VO, Watanabe E. Complete denture biofilm after brushing with specific denture paste, neutral soap and artificial saliva. Braz Dental J 2013;24:47-52.

7. Sorgini DB, Silva-Lovato $\mathrm{CH}$, Souza RF, Davi LR, Paranhos HFO. Abrasiveness of conventional and specific denture-cleansing dentifrices. Braz Dent J 2012;23:154-159. 
8. Gornitsky M, Paradis I, Landaverde G, Malo AM, Velly AM. A clinical and microbiological evaluation of denture cleansers for geriatric patients in long-term care institutions. J Can Dent Assoc 2002;68:39-45.

9. Council on Dental Materials, Instruments and Equipments. Denture cleansers. J Am Dent Assoc 1983;106:77-79.

10. Cruz PC, Andrade IM, Peracini A, Souza-Gugelmin MC, Silva-Lovato CH, Souza RF, et al.. The effectiveness of chemical denture cleansers and ultrasonic device in biofilm removal from complete dentures. J Appl Oral Sci 2011;19:668-673.

11. Andrade IM, Cruz PC, Silva-Lovato CHL, Souza RF, Paranhos HFO, Candido RC, et al.. Effervescent tablets and ultrasonic devices against Candida and mutans streptococci in denture biofilm. Gerodontol 2011;28:264-270

12. Webb BC, Thomas J, Whittle T. A 2-year of Candida-associated denture stomatitis treatment in aged care subjects. Gerodontol 2005;22:168176.

13. Laureano Filho JR, Andrade ESS, Albergaria-Barbosa JR, Camargo IB, Garcia RR. Effects of demineralized bone matrix and a "Ricinus communis" polymer on bone regeneration: a histological study in rabbit calvaria. J Oral Sci 2009;51:451-456.

14. Meneghin MP, Nomelini SMB, Souza-Neto MD, Marchesan MA, França SC, Santos HSL. Morphologic and morphometric analysis of the root canal apical third cleaning after biomechanical preparation using 3.3\% Ricinus communis detergent and $1 \% \mathrm{NaOCl}$ as irrigating solutions. J App Oral Sci 2006;14:178-182.

15. Pinelli LAP, Montandon AAB, Corbi SCT, Moraes TA. Ricinus communis treatment of denture stomatitis in institutionalized elderly. J Oral Rehabil 2013:40:375-380.

16. Pisani MX, Macedo AP, Paranhos HFO, Silva-Lovato $\mathrm{CH}$. Effect of experimental Ricinus communis solution for denture cleaning on the properties of acrylic resin teeth. Braz Dent J 2012;23:15-21.
17. Pisani MX, Silva-Lovato $\mathrm{CH}$, Paranhos HFO, Souza RF, Macedo AP. Evaluation of experimental cleanser solution of Ricinus communis: effect on soft denture liner properties. Gerodontol 2012;29:179-185.

18. Souza RF, Paranhos HFO, Silva-Lovato $\mathrm{CH}$, Abu-Naba'a L, Fedorowicz $Z$, Gurgan CA. Interventions for cleaning dentures in adults. Cochrane Database of Systematic Reviews 2009;7:CD007395.

19. Kempler D, Myer M, Kahl EA, Martin DW. The efficacy of sodium hypochlorite as a denture cleanser. Spec Care Dentist 1982;2:112-115.

20. Kulak Y, Arikan A, Albak S, Okar I, Kazazoglu E. Scanning electron microscopic examination of different cleaners: surface contaminant removal from dentures. J Oral Rehabil 1997;24:209-215.

21. Lima EMCX, Moura JS, Del Bel Cury AA, Garcia RCMR, Cury JA. Effect of enzymatic and $\mathrm{NaOCl}$ treatments on acrylic roughness and biofilm accumulation. J Oral Rehabil 2006;33:356-362.

22. Burdock GA, Carabin IG, Griffiths JC. Toxicology and pharmacology of sodium ricinoleate. Food Chem Toxicol 2006;44:1689-1698.

23. Merkle HP, Higuchi WI. Effects of antibacterial microenvironment in vitro plaque formation of Streptococcus mutans as observed by scanning electron microscopy. Arzneimittelforschung 1980;30:18411846.

24. Mordenti JJ, Lindstrom RE, Tanzer JM. Activity of sodium ricinoleate against in vitro plaque. J Pharm Sci 1982;71:1419-1421.

25. Paranhos HFO, Silva-Lovato CH, Souza RF, Cruz PC, Freitas-Pontes KM,

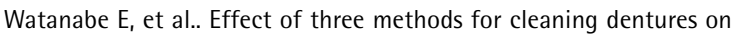
biofilm formed in vitro on acrylic resin. J Prosthodont 2009;18:427431.

Received September 2, 2013 Accepted November 22, 2013 